\title{
Penilaian kualitas visual beberapa bentuk tajuk pohon di median Jalan Prof. Dr. Ida Bagus Mantra menggunakan simulasi komputer
}

\author{
Sang Ayu Putu Gitariani Murna¹, I Gst. A. A. Rai Asmiwyati ${ }^{1 *}$ I Made Sukewijaya². \\ 1. Program Studi Arsitektur Pertamanan, Fakultas Pertanian, Universitas Udayana, Jl. P.B. Sudirman, \\ Denpasar, Indonesia \\ 2. Program Studi Agroekoteknologi, Fakultas Pertanian, Universitas Udayana, Jl. P.B. Sudirman, Denpasar, \\ Indonesia \\ *E-mail: asmiwyati@unud.ac.id
}

\begin{abstract}
Visual Quality Assessment of Tree Canopy Shape on Prof. Dr. Ida Bagus Mantra Parkway Uses Computer Simulation. Trees in the streetscape have important function and aesthetic roles. Trees can serve as a beautification and functional complement, unifier, reinforcement, marker and frame of the environment. The shape of the tree canopy is the most prominent. It is not only visually aesthetic, but also has an ecological function. This study aim to evaluate the visual quality of tree canopy shape on Prof. Dr. Ida Bagus Mantra that able to fulfil the psychological needs of users by using the aesthetic assessment indicator of Scenic Beauty Estimation (SBE). The methods used in this study were survey and data collection techniques were observation to determine the location point that will be used as a simulation as well as a questionnaire to determine the value of SBE and the preferences of users. The results showed that the value of tree canopy aesthetic taken in seven canopy shape simulations, which had the highest SBE value is with globular (rounded) canopy which located in Prof. Dr. Ida Bagus Mantra median strip. The medium SBE value was fastigiated canopy, pyramidal (cone) canopy, weeping canopy, picturesque canopy, and spread canopy. Columnar canopy had a low visual quality, which means that rhe photo of the canopy shape was less attractive.
\end{abstract}

Keywords: aesthetic, median strip, Scenic Beauty Estimation, tree canopy shape.

\section{Pendahuluan}

Jalan sebagai sarana transportasi utama penghubung darat merupakan akses sirkulasi penting dalam memperlancar fungsi dan aktivitas suatu kawasan. Lanskap jalan berperan dalam membangun karakter lingkungan, spasial dan visual sehingga dapat memberikan kesan dari suatu kawasan serta menciptakan identitas perkotaan (Simonds, 1983). Pada umumnya pembuatan jalur hijau di kawasan sepanjang jalan untuk memberikan kenyamanan dan keamanan pengguna, serta menciptakan keseimbangan lingkungan dan estetika. Jenis tanaman yang dominan digunakan dalam membentuk lanskap jalan adalah pohon. Dinyatakan pula unsur tanaman yang paling menonjol ialah bentuk, ukuran, tekstur dan warna (Lestari dan Gunawan, 2010). Bentuk tajuk pada pohon merupakan karakteristik pohon yang paling menonjol tidak hanya secara estetika visual tetapi sebagai fungsi ekologi.

Salah satu lanskap jalan yang terdapat di Pulau Bali yaitu lanskap Jalan Prof. Dr. Ida Bagus Mantra yang terdapat di Kabupaten Klungkung, Kabupaten Gianyar dan Kota Denpasar. Jalan Prof. Dr. Ida Bagus Mantra memiliki median jalan yang cukup lebar untuk memisahkan jalan tersebut dan ditanami berbagai jenis pohon dengan tiga bentuk tajuk pohon, yaitu bentuk tajuk kubah, spread (menyebar), dan picturesque (menarik). Bentuk tajuk pohon yang mendominasi adalah bentuk tajuk spread (menyebar), dan bentuk tajuk kubah. Menurut Booth (1983), dikenal tujuh jenis bentuk tajuk pohon antara lain, globular (membulat), columnar (tinggi, meramping), spread (menyebar), picturesque (menarik), weeping (menjurai), pyramidal (kerucut), dan fastigiate (tinggi ramping, meruncing). Hal ini menunjukkan masih rendahnya eksplorasi penggunaan jenis pohon dengan variasi bentuk tajuk pohon yang memiliki estetika. Median Jalan Prof. Dr. Ida Bagus Mantra seharusnya dapat memberikan nilai keindahan visual yang optimal bagi pengendara.

Penelitian ini mencoba mensimulasikan bentuk tajuk pohon ke median jalan Prof. Dr. Ida Bagus Mantra. Pemilihan median jalan Prof. Dr. Ida Bagus Mantra sebagai lokasi penelitian karena hanya median jalan 
tersebut memiliki lebar lebih dari 5 meter sehingga memenuhi syarat keamanan untuk ditanami pohon, sedangkan median jalan lainnya di Provinsi Bali dominan memiliki lebar 1,5 meter. Menurut Peraturan Menteri Pekerjaan Umum (2012), median jalan yang lebarnya 1,5 meter ditanami tanaman perdu atau semak di median jalan. Simulasi komputer dalam penelitian ini digunakan untuk meniru kondisi nyata dengan menggunakan spot lokasi median jalan Prof. Dr. Ida Bagus Mantra dan beragam jenis pohon dengan berbagai bentuk tajuk yang bersumber dari template. Tujuan yang ingin dicapai dalam penelitian ini adalah mengetahui preferensi responden terhadap kualitas visual dari hasil simulasi bentuk tajuk pohon median Jalan Prof. Dr. Ida Bagus Mantra dan mengetahui nilai kualitas visual dari hasil simulasi bentuk tajuk pohon median Jalan Prof. Dr. Ida Bagus Mantra. Metode yang digunakan dalam studi ini adalah Scenic Beauty Estimation (SBE) melalui pengambilan gambar median jalan, pembuatan simulasi dengan template foto pohon, serta analisis data.

\section{Metode}

Penelitian ini dilakukan di koridor Jalan Prof. Dr. Ida Bagus Mantra yang membentang mulai dari Kota Denpasar, Kabupaten Gianyar, hingga Kabupaten Klungkung, Bali. Penelitian dimulai pada bulan Juli 2018 sampai Januari 2019. Alat yang digunakan dalam penelitian ini adalah peta dari Google Earth sebagai penentuan lokasi atau sebagai batasan dari lokasi yang diteliti, kamera digital untuk memotret, dan perangkat lunak Adobe Photoshop CS3. Bahan yang digunakan pada penelitian ini adalah kuesioner sebagai bahan persepsi pengguna dan template foto bentuk tajuk pohon.

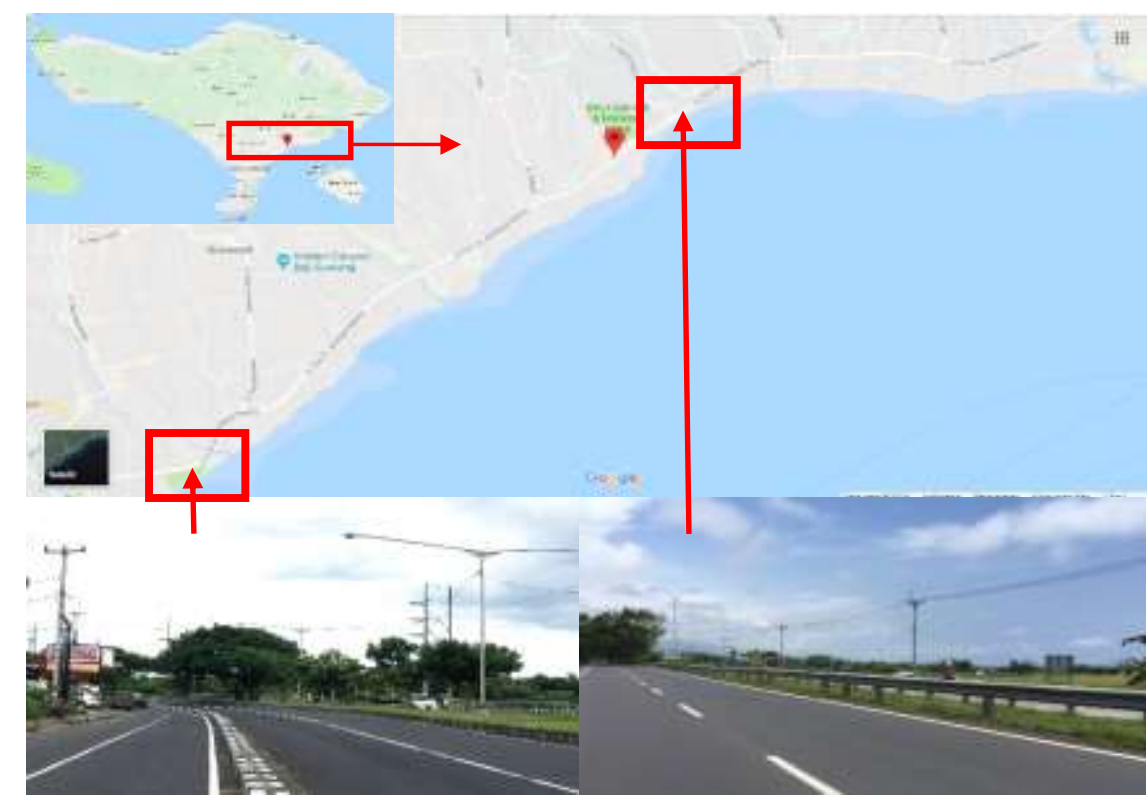

Gambar 1. Peta Lokasi Penelitian Jalan Prof. Dr. Ida Bagus Mantra

(Sumber: Google Maps 2019)

\subsection{Metode Penelitian}

Metode penelitian yang digunakan dalam penelitian ini adalah metode studi pustaka dan motode survei dengan teknik pengambilan data observasi dan kuesioner. Dalam upaya mencapai tujuan penelitian dilakukan dalam beberapa tahapan, yaitu:

1. Tahap Persiapan

Tahap kegiatan ini dimulai dengan studi pustaka untuk menguasai metode SBE yang digunakan dalam penelitian ini. Kegiatan selanjutnya adalah survei lapang untuk melakukan observasi. Data yang diperoleh berupa gambar atau foto lokasi yang digunakan sebagai simulasi. Foto lokasi yang diambil berjumlah dua buah, foto dengan keadaan jalan lurus dan foto dengan keadaan jalan berbelok untuk mewakili kondisi jalan utama. Foto lokasi jalan dipilih bagian yang dirasakan paling representatif.

2. Tahap Pengambilan Data 
Data yang diambil adalah berupa foto lokasi Jalan Prof. Dr. Ida Bagus Mantra yang sudah ditentukan sebelumnya. Pengambilan foto pada kawasan Jalan Prof. Dr. Ida Bagus Mantra dan pohon yang digunakan sebagai simulasi dilakukan tidak terbatas waktu. Pemotretan dilakukan melalui sudut pandang pengguna saat berkendara.

Bentuk tajuk pohon disesuaikan dengan contoh bentuk tajuk menurut Booth (1983). Pohon-pohon yang digunakan sebagai simulasi memiliki persyaratan, guna meningkatkan fungsi dan peran serta estetika jalan untuk kelancaran transportasi darat dan pada saat yang bersamaan juga untuk keamanan pengguna kendaraan dan pengguna jalan (Nurisyah dan Adriani, 2015). Persyaratan pohon sebagai berikut:

a. Ketinggian dan ukuran pohon tidak akan mengganggu sarana dan prasarana kota yang berada di sepanjang jalan

b. Pohon memiliki nilai estetika, bentuk yang rapi dan tidak menakutkan

c. Pohon harus mempunyai cabang dan batang yang kuat sehingga tidak mudah patah

d. Pohon berasal dari hasil pembiakan generatif melalui benih

e. Tidak memiliki buah yang besar

Menurut Nurisyah dan Adriani (2015), jalan yang cukup lebar sebaiknya memilih jenis tanaman yang mengikuti karakter jalan yaitu pohon-pohon yang ukurannya besar. Pohon yang mendekati persyaratanpersyaratan yang telah ditentukan digunakan untuk pembuatan simulasi. Pemilihan pohon jenis pohon menghasilkan beberapa jenis pohon yaitu Populus nigra (Poplas hitam), Samanea saman (Ki hujan), Pterocarps indicusn (Angsana), Salix babylonica (Dedalu), Araucaria heterophylla (Cemara Norfolk), Polyalthia longifolia (Glodogan tiang) dan Filicium decipiens (Kirai payung). Selanjutnya foto lokasi dan bentuk tajuk pohon yang memenuhi kriteria pohon tepi jalan diedit menggunakan software Adobe Photoshop CS3. Manipulasi foto ini mampu mengkomunikasikan hubungan dan bentuk visual karena foto merupakan representasi kenyataan yang paling mendekati (Laurie, 1990). Aplikasi Adobe Photoshop CS3 membantu untuk pembuatan, penyuntingan dan manipulasi tampilan termasuk koreksi warna, pemberian efek tampilan pada foto simulasi.

Satu bentuk tajuk pohon dibuat dua simulasi dengan tipe jalan lurus dan berbelok, jadi total simulasi yang dibuat berjumlah 14 dan ditata dalam 7 (tujuh) paket foto. Hasil foto yang telah disimulasi kemudian ditata untuk dijadikan tabel kuesioner SBE dengan rentang nilai 1 (tidak suka) - 10 (suka). Responden memberikan penilaian untuk setiap paket foto simulasi, satu paket foto simulasi memiliki satu nilai SBE. Responden terdiri atas satu kategori responden yaitu responden pengguna jalan atau umum dengan jumlah 70 orang. Pengambilan responden dilakukan berdasarkan acuan umum, jumlah responden lebih dari 30 dan kurang dari 500 adalah tepat untuk kebanyakan penelitian (Sekaran, 2006). Penyebaran dilakukan pada tanggal 1 Februari 2019 sampai dengan 4 Februari 2019. Penyebaran kuesioner dilakukan tanpa mengunjungi lokasi penelitian namun dilakukan menggunakan survey daring yaitu Google form untuk mengefisienkan waktu, link Gooble form dari kuesioner penelitian ini disebarkan ke responden melalui pesan singkat. Penggunaan survey daring juga dapat menghemat biaya karena tidak perlu mencetak kuesioner.

3. Tahap Pengolahan Data

Hasil kuesioner yang didapat dilakukan inputing data dalam bentuk tabulasi skor resonden. Pertama data kuesioner SBE setiap foto simulasi dikelompokkan berdasarkan skala penilaian 1 sampai 10. Selanjutnya setiap foto simulasi dihitung jumlah frekuensi (f), frekuensi kumulatif (cf), peluang kumulatif (cp) dan, nilai z untuk setiap peringkat dari skor penilaian yang didapat (Daniel and Booster, 1976). Perbandingan dalam perhitungan nilain SBE adalah lanskap atau foto yang memiliki rata-rata nilai z mendekati 0 . Formulasi perhitungan nilai SBE adalah:

$$
S B E x=[Z x-Z s] \times 100
$$

Dimana SBEx = Nilai pendugaan keindahan pemandangan lanskap ke- $x$

$Z x=$ Nilai rata-rata $z$ lanskap ke- $x$

$Z s=$ Nilai rata-rata $z$ lanskap yang digunakan sebagai standar atau $z$ smallest 


\section{$2.2 \quad$ Sintesis Data}

Tahap sintesis adalah tahap pemecahan masalah untuk penelitian yang telah dilakukan. Tahap sintesis dalam penelitian ini adalah mencari kualitas visual bentuk tajuk pohon melalui penilaian SBE menggunakan kuesioner daring. Selanjutnya diperoleh rekomendasi bentuk tajuk yang dapat digunakan di median jalan Prof. Dr. Ida Bagus Mantra dengan hasil preferensi responden.

\subsection{Batasan Penelitian}

Penelitian ini dibatasi sampai pada tahap pengambilan data kuantitatif melalui kuesioner untuk menilai kualitas visual bentuk tajuk pohon median Jalan Prof. Dr. Ida Bagus Mantra menggunakan simulasi komputer, preferensi responden, serta rekomendasi bentuk tajuk pohon. Penilaian kualitas visual dibatasi pada keindahan tajuk pohon pada jalan, tidak menguji nilai keindahan bentuk tajuk pohon pada 2 (dua) tipe jalan yang berbeda.

\section{Hasil dan Pembahasan}

\subsection{Gambaran Umum Jalan Prof. Dr. Ida Bagus Mantra}

Lanskap jalan yang terdapat di Pulau Bali yaitu Jalan Prof. Dr. Ida Bagus Mantra yang terdapat di Kabupaten Klungkung, Kabupaten Gianyar dan Kota Denpasar. Jalan Prof. Dr. Ida Bagus Mantra memiliki panjang jalan $28 \mathrm{~km}$ dan lebar lajur utama $7 \mathrm{~m}$ kiri $7 \mathrm{~m}$ kanan serta memiliki lebar median jalan 6,5 $\mathrm{m}$ sampai $7 \mathrm{~m}$. Jalan tersebut memiliki empat lajur yaitu dua lajur utama serta dua lajur lambat, namun hanya sebagian jalan yang memiliki empat lajur sebagian lainnya hanya memiliki dua lajur. Pada kanan dan kiri Jalan Prof. Dr. Ida Bagus Mantra terdapat pemukiman yang cukup padat pada km 1-15, selanjutnya yaitu km 15 dan seterusnya kepadatan mulai menurun hal ini dapat dilihat dari bangunan yang memiliki jarak cukup jauh. Pada $\mathrm{km} 15$ terdapat sawah atau kebun masyarakat yang terdapat di sisi kanan kiri jalan.

Jalan Prof. Dr. Ida Bagus Mantra dengan lebar 30 meter ditata dengan membuat median jalan yang ditanami 5 (lima) jenis pohon untuk memberikan keteduhan. Fungsi lain dari median jalan selain fungsi ekologi adalah fungsi estetika yaitu bertujuan menghilangkan kebosanan saat berkendara bagi pengguna jalan. Median jalan ini seharusnya dapat memberikan visual yang baik bagi pengendara, karena Jalan Prof. Dr. Ida Bagus Mantra merupakan salah satu akses utama yang berada di Bali.

Jalan Prof. Dr. Ida Bagus Mantra secara umum memiliki kondisi biofisik yang serupa dengan Kota Denpasar, yang memiliki iklim tropis dengan musim kemarau yang lebih panjang, suhu udara rata-rata mencapai $29,8^{\circ} \mathrm{C}$ dengan rata-rata nilai terendah $24,3^{\circ} \mathrm{C}$. Tingkat curah hujan rata-rata sebesar $244 \mathrm{~mm}$ dan curah hujan rata-rata pertahun $2.181 \mathrm{~mm}$ serta kelembaban udara rata-rata berkisar antara $60 \%-97 \%$ dan pada musim panas bisa mencapai $60 \%$. Kondisi iklim ini memungkinkan tanaman di median jalan untuk tumbuh dengan baik. Kebutuhan air di musim panas harus senantiasa dipastikan untuk bisa dipenuhi dengan baik. Kondisi topografi berada di dataran rendah dengan ketinggian berkisar antara $0-75 \mathrm{~m}$ dpl dan memiliki jenis tanah mediterian yang kurang peka terhadap erosi. Kondisi di tepi laut mensyaratkan pemilihan jenis tanaman di median jalan juga memiliki tingkat toleransi garam dan kekeringan yang tinggi sampai sedang. Tabel 1 menunjukkan keragaman vegetasi yang terdapat di Jalan Prof. Dr. Ida Bagus Mantra.

Tabel 1. Keragaman Vegetasi di Median Jalan Prof. Dr. Ida Bagus Mantra

\begin{tabular}{lll}
\hline No & Jenis Tanaman & Nama Tanaman \\
\hline 1 & Semak & Bunga Kertas (Bougainvillea sp.) \\
2 & Pohon & Ki Hujan (Samanea saman) \\
3 & Pohon & Mahoni (Swietenia mahagoni) \\
4 & Pohon & Kamboja (Plumeria sp.) \\
5 & Pohon & Tabebuya (Tabebuai aurea) \\
6 & Pohon & Bungur (Lagerstromia speciosa Pers.)
\end{tabular}




\subsection{Penilaian Kualitas Visual}

Hasil dari penilaian kualitas visual berupa kuesioner oleh responden merupakan skor untuk masingmasing foto. Terdapat 7 (tujuh) paket foto yang setiap paketnya berisi dua foto mencakupi dua area Jalan Prof. Dr. Ida Bagus Mantra. Setiap area memiliki 7 (tujuh) buah foto sebagai perwakilan dari masing-masing bentuk tajuk pohon. Rata-rata nilai setiap foto lanskap yang diperoleh dari hasil penilaian responden kemudian dimasukkan dalam rumus SBE. Skor tertinggi (nilai SBE tinggi) menunjukkan bahwa lanskap tersebut paling banyak dipilih sebagai lanskap yang indah, sedangkan skor rendah (nilai SBE rendah) menggambarkan lanskap yang jelek (tidak disukai). Setiap sebaran nilai SBE diklasifikasikan menjadi tiga kelas yang menunjukkan kategori keindahan lanskap yang rendah, sedang, dan tinggi (Budiyono, 2015). Kisaran besaran nilai mulai dari 0 - 150 selengkapnya dapat dilihat pada tabel.

Tabel 2. Besaran Nilai Kualitas Visual

\begin{tabular}{cc}
\hline Kategori & Batas Nilai \\
\hline Tinggi & $100-150$ \\
Sedang & $50-100$ \\
Rendah & $0-50$ \\
\hline
\end{tabular}

Tabel 3 menunjukkan foto simulasi bentuk tajuk pohon median jalan Prof. Dr. Ida Bagus Mantra yang digunakan sebagai kuesioner. Seluruh foto tersebut kemudian dijadikan bahan penelitian penilaian kualitas visual bagi responden. Masing-masing paket foto simulasi dinilai oleh 70 responden yang memberikan nilai untuk dimasukkan ke rumusan SBE. Nilai berupa nilai frekuensi (f), frekuensi kumulatif (cf), peluang kumulatif (cP) dan Zscore. Nilai rata-rata Z kemudian dimasukkan kedalam rumusan SBE yang menghasilkan nilai SBE pada masing-masing foto lanskap.

Tabel 3. Paket Foto Simulasi Bentuk Tajuk Pohon Jalan Prof. Dr. Ida Bagus Mantra

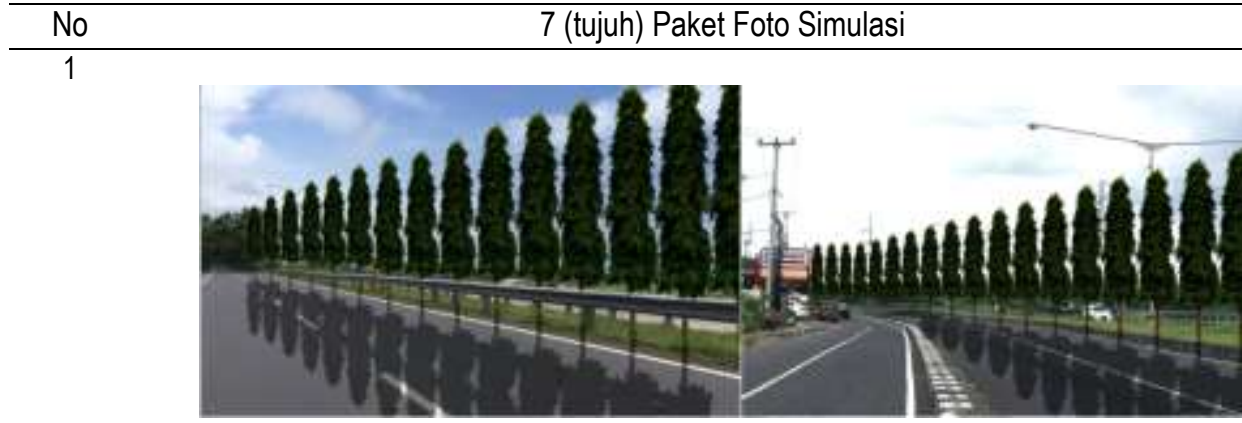

Foto Simulasi Bentuk Tajuk Pohon Fastigiated (Ramping, Meruncing). Pohon yang mewakili Glodokan Tiang (Polyalthia longifolia)

2

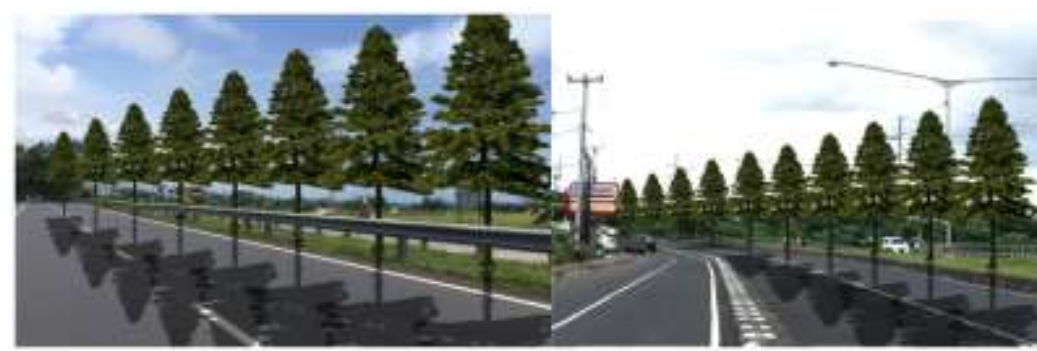

Foto Simulasi Bentuk Tajuk Pohon Pyramidal (Kerucut). Pohon yang mewakili Cemara Norfolk (Araucaria heterophylla)

(Sumber: https://www.alamy.com/stock-photo-norfolk-pine-tree-manly-beach-sydneyaustralia-35066265.html.) 


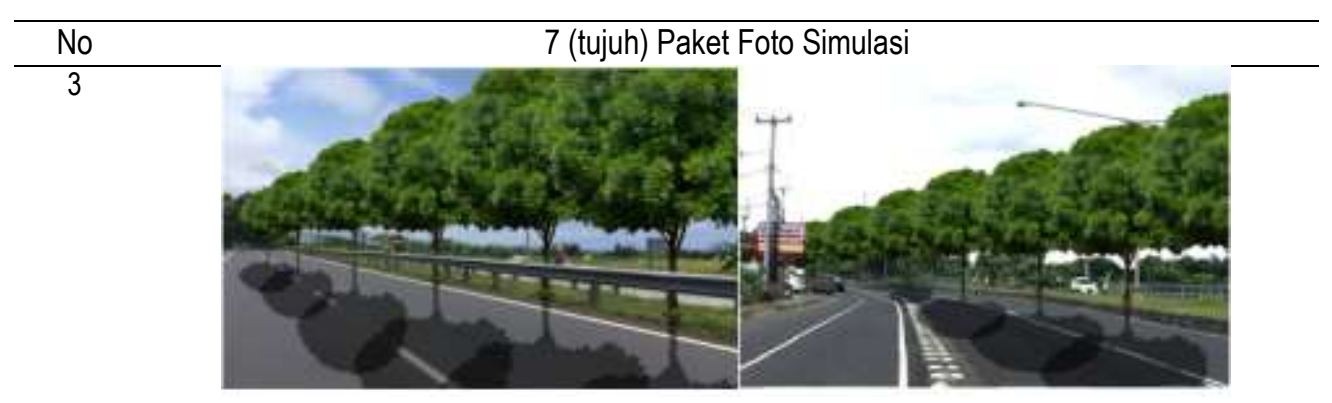

Foto Simulasi Bentuk Tajuk Pohon Globular (Membulat). Pohon yang mewakili Kirai Payung (Filicium decipiens)

(Sumber: https://www.kisspng.com/png-acer-ginnala-populus-sect-aigeiros-tree-hardwood-s863550/.)

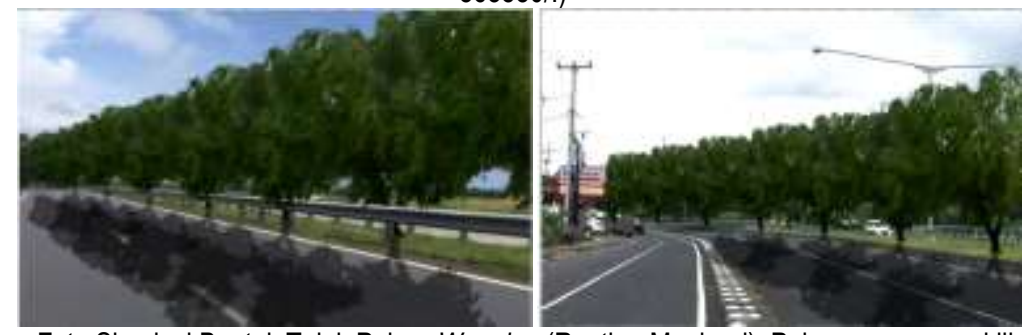

Foto Simulasi Bentuk Tajuk Pohon Weeping (Ranting Menjurai). Pohon yang mewakili Dedalu (Salix babylonica)

(Sumber: https://www.seekpng.com/ipng/u2w7y3t4w7q8w7t4_salix-babylonica/.)
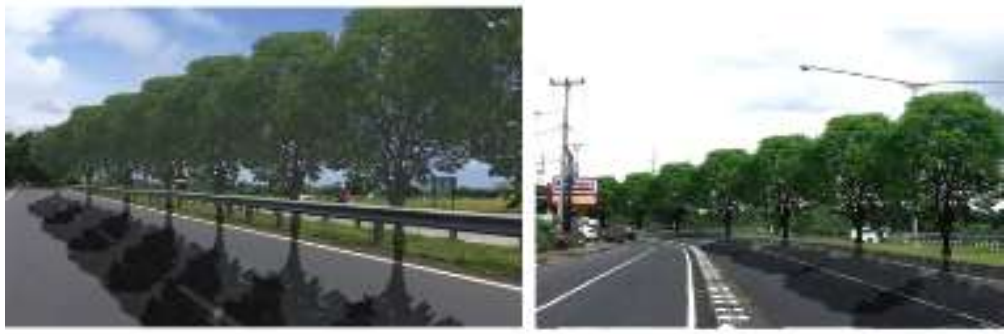

Foto Simulasi Bentuk Tajuk Pohon Picturesque (Menarik). Pohon yang mewakili Angsana (Pterocarpus indicus)

(Sumber: http://pluspng.com/narra-png-2351.html.)

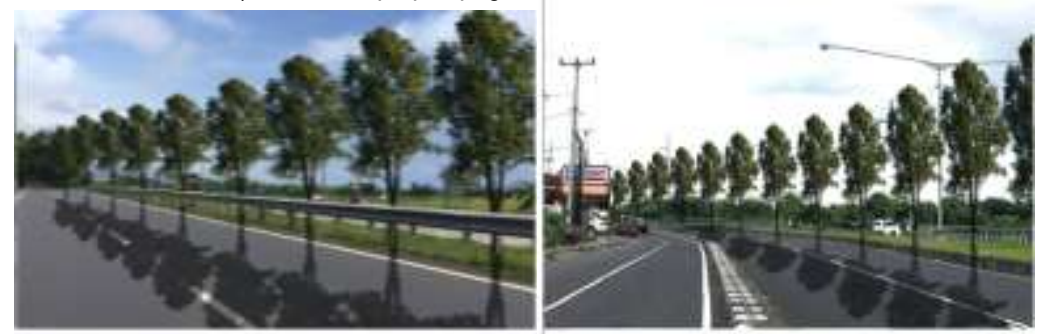

Foto Simulasi Bentuk Tajuk Pohon Columnar (Tinggi, Meramping). Pohon yang mewakili Poplas Hitam (Populus nigra)

(Sumber: https://www.cutouttrees.com/collections/frontpage/products/populus-nigra-iv)

7

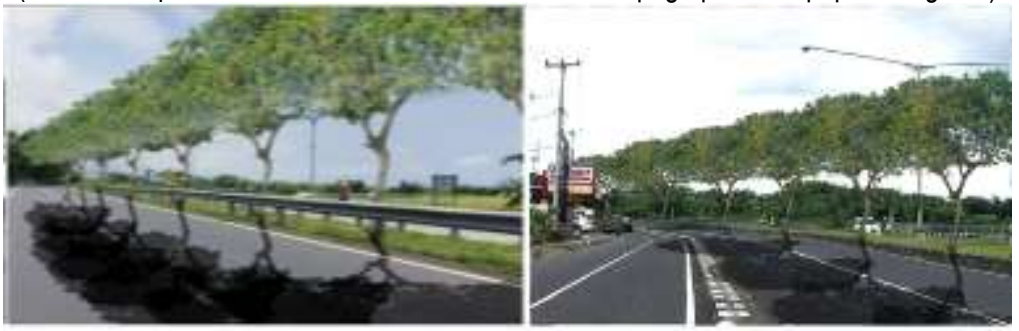

Foto Simulasi Bentuk Tajuk Pohon Spread (Menyebar). Pohon yang mewakili Ki Hujan (Samanea saman).

(Sumber: www.pngkey.com/detail/u2e6t4y3y3q8r5e6_mature-tree-height samanea-saman-png.) 


\subsection{Perhitungan Nilai SBE}

Setiap spesies pohon memiliki karakteristik yang secara visual mudah dikenali terutama dari bentuk pohon tersebut. Secara visual bentuk tajuk pohon merupakan komponen visual yang paling mudah dan cepat dikenali melalui indera penglihatan karena terlihat dominan dan memiliki ukuran yang lebih mencolok dibandingkan bagian lain (Lestari dan Gunawan, 2010). Hal ini diperkuat oleh pernyataan Simonds (1983), bahwa bagian pohon yang paling menarik adalah kanopi atau tajuk pohon karena dapat memberikan identitas dan karakter pada lingkungan. Kerindangan atau bayangan yang ditimbulkan oleh pohon akibat sinar cahaya merupakan unsur lain yang mampu menarik perhatian responden dan berkaitan erat dengan ukuran dan bentuk tajuk.

Penilaian kualitas visual bentuk tajuk pohon menunjukkan terjadinya perubahan nilai untuk setiap foto simulasi yang ditampilkan. Foto simulasi dengan bentuk tajuk pohon horizontal cenderung memiliki kualitas visual yang lebih tinggi dibandingkan pohon bertajuk vertikal. Unsur vertikal pada ruang menimbulkan kesan kaku, tegas, stabil dan kuat. Pohon bertajuk vertikal kurang dapat menciptakan kesan ruang yang nyaman dan teduh karena tajuk sempit sehingga tidak dapat memberikan keteduhan pada area yang lebih luas (Lestari dan Gunawan, 2010). Menurut Simonds (1983), dominasi unsur-unsur horizontal pada ruang menimbulkan kesan santai, rileks dan tenang. Unsur horizontal pada pohon ditunjukkan oleh pohon bertajuk bulat, menyebar, menjurai dan menarik sedangkan unsur vertikal secara dominan ditunjukkan oleh pohon bertajuk fastigiate, kerucut dan columnar. Pohon dengan unsur horizontal direpresentasikan oleh pohon bertajuk bulat dan menyebar yang memiliki kualitas estetika tinggi hingga sedang. Bentuk tajuk pohon bulat dan menyebar kebanyakan memiliki cara percabangan simpodial, yaitu batang pokok sukar ditentukan atau batang pokok kalah besar dan kalah cepat pertumbuhannya dibandingkan dengan cabangnya (Tjitrosoepomo, 1985). Bentuk tajuk tersebut biasanya juga membentuk sudut percabangan mendatar atau horizontal sehingga mampu memberikan keteduhan pada area yang lebih luas.

Hasil perhitungan SBE menunjukkan bahwa kualitas estetika lanskap jalan berkisar antara 0 sampai 104,34. Nilai SBE ini menunjukkan estetika lanskap dari yang tertinggi hingga terendah terhadap lanskap standar. Pada penilaian ini, sebagian besar responden menilai pada skala diatas 5 (lima) sehingga nilai SBE sebagian besar berada diatas nilai lanskap standar dan terdapat satu nilai SBE yang berada dibawah nilai standar yaitu foto nomor enam. Gambar 2 menunjukkan nilai SBE dan kategori kualitas visual.

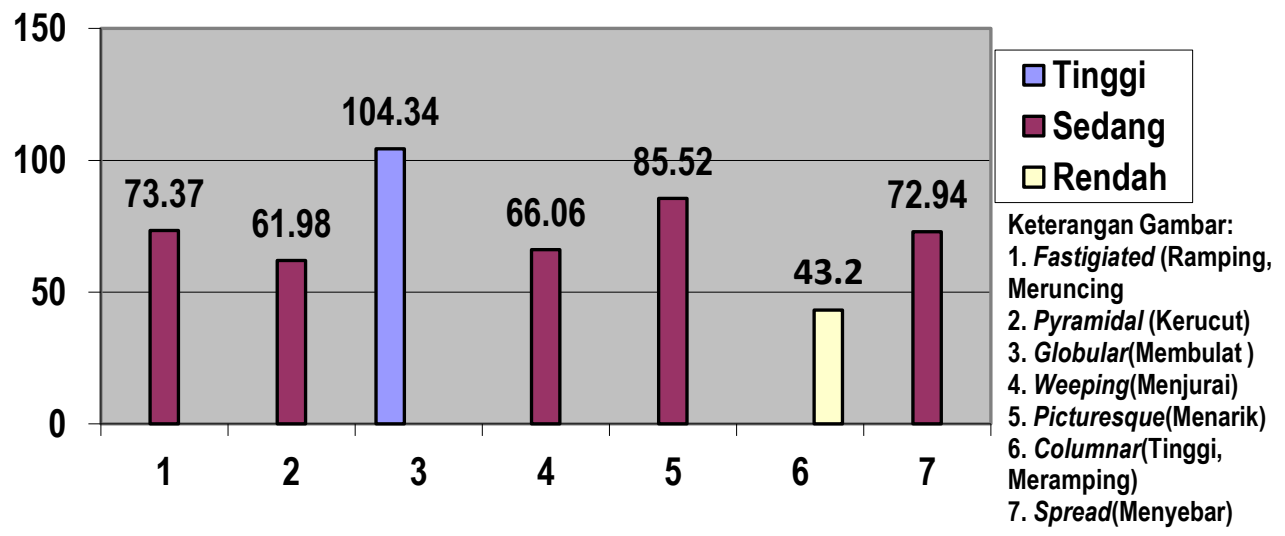

Gambar 2. Nilai SBE dan Kategori Kualitas Visual

Foto simulasi bentuk tajuk pohon yang memiliki nilai tertinggi adalah foto simulasi nomor tiga dengan bentuk tajuk pohon globular (membulat) dengan nilai SBE 104.34. Lampiran 2 menunjukkan hasil perhitungan nilai SBE tertinggi bentuk tajuk pohon median Jalan Prof. Dr Ida Bagus Mantra. Lanskap yang memiliki nilai pendugaan estetika tertinggi merupakan lanskap yang paling disukai atau indah (Daniel and Booster, 1976). Pohon yang digunakan pada simulasi foto bentuk tajuk globular (membulat) adalah kirai payung (Filicium 
decipiens). Pada foto simulasi bentuk tajuk globular (membulat) terlihat bentuk tajuk pohon memiliki bentuk yang teratur dan lembut, tajuk pohon juga dapat menaungi pengguna jalan dengan baik. Hal ini dapat disimpulkan bahwa responden cenderung lebih menyukai median jalan yang ditanami pohon dengan bentuk tajuk globular (membulat) karena bentuk tajuk tersebut memberikan suasana teduh dan nyaman. Hasil ini didukung oleh penelitian Lestari dan Gunawan (2010), bahwa responden cenderung lebih menyukai lanskap jalan dengan suasana teduh dan nyaman.

Keharmonisan antara bentuk jalan yang vertikal dan bentuk tajuk membulat memberi kesan langkung atau alami sehingga mengurangi bentuk jalan yang keras dan tegas. Hal ini baik untuk pengguna jalan karena bersifat tidak monoton (Budiyono, 2015). Pada bentuk tajuk globular (membulat) memiliki unsur horizontal yang dikombinasikan dengan Jalan Prof. Dr. Ida Bagus Mantra yang memiliki unsur vertikal menciptakan keseimbangan yang menampilkan visual yang bervariasi. Hasil ini didukung oleh pernyataan Hakim (2014), bahwa perasaan persamaan berat, perhatian atau daya tarik dari berbagai elemen yang menyenangkan dalam suatu desain sehingga menghasilkan susunan yang menarik. Suatu susunan yang tidak seimbang menimbulkan konflik atau pertentangan terutama dari sudut visual.

Menurut Departemen PU Ditjen Bina Marga (2010), pada standar teknik jalan yang ditetapkan oleh Departemen PU Bina Marga mengenai kriteria pohon yang digunakan sebagai pohon tepi jalan pada jalan dalam kota hanya merekomendasikan pohon bertajuk bulat dan columnar. Pohon dengan bentuk tajuk globular (membulat) selain memiliki kualitas visual yang tinggi bentuk tajuk tersebut juga merupakan rekomendasi dari Departemen PU Ditjen Bina Marga (2010), hal ini dapat menjadi nilai tambah pada pohon dengan bentuk tajuk globular (membulat). Beberapa pohon dengan bentuk tajuk globular (membulat) yang dapat digunakan pada median jalan adalah Filicium decipiens (kerai payung), Mimusops elengi (tanjung), Polyalthia fragrans (glodogan bulat), dan Pometia pinnata (matoa).

Nilai SBE sedang terdapat pada foto nomor tujuh dengan bentuk tajuk pohon spread (menyebar) dengan nilai SBE 72,94. Karakter lanskap kualitas estetika sedang merupakan karakter perpaduan antara lanskap kualitas tinggi dan rendah (Lestari dan Gunawan, 2010). Pohon yang digunakan pada simulasi foto nomer tujuh adalah ki hujan (Samanea saman). Pada foto simulasi nomor tujuh terlihat bentuk tajuk pohon memiliki bentuk yang menarik karena pada dahan pohon memiliki percabangan yang menyebar sehingga tajuk yang terbentuk lebih rimbun dan pengguna jalan ternaungi dengan baik. Menurut Hakim dan Utomo (2008), bahwa bentuk menyebar memberi kesan alami karena bentuk tajuk yang tidak teratur. Foto simulasi yang termasuk dalam kategori sedang berarti telah memiliki bentuk tajuk yang cukup memiliki visual menarik dan cukup diminati oleh pengguna. Lampiran 2 menunjukkan perhitungan nilai SBE sedang bentuk tajuk pohon median Jalan Prof. Dr Ida Bagus Mantra. Nilai SBE sedang lainnya adalah foto nomor satu dengan bentuk tajuk pohon fastigiated (ramping, meruncing), foto nomor dua dengan bentuk tajuk pyramidal (kerucut), foto nomor empat dengan bentuk tajuk weeping (menjurai), foto nomor lima dengan bentuk tajuk picturesque (menarik).

Nilai SBE terendah terdapat pada foto nomor enam bentuk tajuk pohon columnar (tinggi, meramping) dengan nilai SBE 43,20. Lanskap yang memiliki nilai pendugaan estetika terendah merupakan lanskap yang tidak disukai Daniel and Booster (1976). Pohon yang digunakan pada simulasi foto nomor enam adalah poplas hitam (Populus nigra). Lampiran 2 menunjukkan perhitungan nilai SBE rendah bentuk tajuk pohon median Jalan Prof. Dr Ida Bagus Mantra. Pada foto simulasi nomor enam terlihat bentuk pohon yang ramping dan pohon memiliki dahan yang jarang-jarang sehingga tajuk pohon tidak dapat menaungi pengguna jalan dengan baik. Hasil ini didukung oleh penelitian Lestari dan Gunawan (2010), bahwa pohon dengan bentuk tajuk columnar memiliki bentuk tajuk vertikal yang unik dan tegas akan sesuai jika difungsikan sebagai tanaman pengarah sirkulasi, pembatas pandangan, dan pembingkai ruang. Foto nomor enam memiliki kualitas visual atau nilai keindahan yang rendah yang berarti foto simulasi bentuk tajuk tersebut kurang diminati. Bentuk tajuk pohon columnar memiliki cara percabangan monopodial, yaitu batang pokok selalu tampak jelas karena lebih besar dan lebih panjang atau lebih cepat pertumbuhannya daripada cabang-cabangannya (Tjitrosoepomo, 1985). Hal ini menyebabkan percabangan pohon terlihat lebih massif dan mengurangi estetika pada pohon dengan bentuk tajuk columnar. Menurut Departemen PU Ditjen Bina Marga (2010), pohon dengan bentuk tajuk columnar merupakan salah satu bentuk tajuk yang direkomendasikan, namun pohon dengan bentuk tajuk columnar menurut pengguna jalan memiliki nilai visual yang rendah. Penutupan vegetasi yang kurang dominan 
terhadap ruang memberikan kesan ruang lebih luas, namun hal ini menyebabkan tapak terkesan gersang sehingga pengguna merasa tidak nyaman berada pada tapak (Lestari dan Gunawan, 2010).

\section{Simpulan}

Berdasarkan hasil penelitian, foto simulasi dengan bentuk tajuk pohon globular (membulat) pada lanskap jalan Prof. Dr. Ida Bagus Mantra merupakan foto simulasi yang paling banyak diminati oleh responden. Foto bentuk tajuk pohon dengan nilai SBE tertinggi adalah foto nomor tiga yaitu foto dengan bentuk tajuk globular (membulat) dengan nilai 104.34. SBE dengan nilai sedang yang berarti foto simulasi bentuk tajuk tersebut cukup diminati adalah foto nomor satu dengan bentuk tajuk pohon fastigiated (ramping, meruncing) dengan nilai 73.37 , foto nomor dua dengan bentuk tajuk pyramidal (kerucut) dengan nilai 61.98 , foto nomor empat dengan bentuk tajuk weeping (menjurai) dengan nilai 66.06, foto nomor lima dengan bentuk tajuk picturesque (menarik) dengan nilai 85.52, dan foto nomor tujuh dengan bentuk tajuk spread (menyebar) 72.94. Foto nomor enam dengan bentuk tajuk columnar (tinggi, meramping) dengan nilai 43.2 memiliki kualitas visual atau nilai keindahan yang rendah yang berarti foto simulasi bentuk tajuk tersebut kurang diminati. Rekomendasi pohon dengan bentuk tajuk globular (membulat) dapat digunakan pada spot median jalan Prof. Dr. Ida Bagus Mantra yang belum seperti Filicium decipiens (kerai payung), Mimusops elengi (tanjung), Polyalthia fragrans (glodogan bulat), dan Pometia pinnata (matoa).

\section{Daftar Pustaka}

Alamy. (2010). Norflok Pine Tree. Available online at: www.alamy.com/stock-photo-norfolk-pine-tree-manlybeach-sydney-australia-35066265.html.

Booth, N. K. (1983). Basic Elements of Landscape Architecture Design. Illnois: Waveland Press Inc.

Budiyono, D. (2015). Evaluasi Estetika Lingkungan Berdasarkan Persepsi Welcome Area Kampus Institut Pertanian Bogor. Buana Sains, Volume 15 No 1: 19-28.

CutoutTrees. (2019). Poplas Nigra IV. Available online at: www.cutouttrees.com/collections/frontpage/products/populus-nigra-iv.

Daniel, T. C., and Boster, R. S. (1976). Measuring landscape esthetics: the scenic beauty estimation method. In USDA Forest Service.

Departemen Pekerjaan Umum Direktoral Jenderal Bina Marga. (2010). Pedoman Teknis Penanaman Pohon pada Sistem Jaringan Jalan. In Pedoman Teknis Penanaman Pohon pada Sistem Jaringan Jalan.

Hakim, R dan Utomo, H. (2008). Komponen Perancangan Arsitektur Lanskap. Jakarta: Bumi Aksara

Hakim, R. (2014). Komponen Perancangan Arsitektur Lanskap. (Edisi Kedua). Jakarta: Bumi Aksara.

Kisspng. (2019). Acer Ginnala, Populus Sect Aigeiros, Tree, Evergreen, Plant PNG. Available online at: www.kisspng.com/png-acer-ginnala-populus-sect-aigeiros-tree-hardwood-s-863550/.

Laurie, M. (1990). Pengantar Kepada Arsitektur Pertamanan (Terjemahan). Bandung: Intermedia Publishing Co.Ltd.

Lestari, G. dan A. Gunawan. (2010). Pengaruh Bentuk Kanopi Pohon Terhadap Kualitas Estetika Lanskap Jalan. Jurnal Lanskap Indonesia, Volume 2 No 1.

NarraPNG. (2017). 20 Tree PNG Images for Architecture. Available online at: http://pluspng.com/narra-png2351.html.

Nurisyah, S., dan H. Adriani. (2015). Pohon Tepi Jalan Kriteria dan Penataan. Jakarta: Ikatan Arsitektur Lanskap Indonesia.

Pngkey. (2018). Mature Tree, Height-Samanea Saman PNG. Available online at: www.pngkey.com/detail/u2e6t4y3y3q8r5e6_mature-tree-height samanea-saman-png/.

Seekpng. (2019). Salix Babylonica. Available online at: www.seekpng.com/ipng/u2w7y3t4w7q8w7t4_salixbabylonica/.

Sekaran, U. (2006). Metode Penelitian Bisnis. Jakarta: Salemba Empat.

Simonds, J. O. (1983). Landscape Architecture. McGraw-Hill Book Company, Inc. New York: McGraw-Hill Book Company, Inc.

Strogatz, S. (2007). The End of Insight in Brockman, John What is your dangerous idea?. New York: HarperCollins.

Tjitrosoepomo, G. (1985). Morfologi Tumbuhan. Yogyakarta: Gadjah Mada University Press. 